\title{
The Utilization of AFAS on Indonesia's Retail Service Expansion to ASEAN Markets
}

\author{
Arie Mardiansyah \\ The Agency of Trade Research and \\ Development \\ Ministry of Trade \\ Jakarta, Indonesia \\ arie.mardiansyah@ymail.com
}

\author{
Kerub Henpra Gokniel \\ The Agency of Trade Research and \\ Development \\ Ministry of Trade \\ Jakarta, Indonesia \\ kerubgokniel@gmail.com
}

\author{
Jane Marisi Rapmeriah \\ The Agency of Trade Research and \\ Development \\ Ministry of Trade \\ Jakarta, Indonesia \\ jane.marisi@kemendag.go.id
}

\begin{abstract}
The utilization of the ASEAN Framework Agreement on Services (AFAS) negotiations by Indonesia's retail industry is still considered low. Retail business expansion to regional market is really expected to increase Indonesia's trade performance and to maximize ASEAN market potential as its economic growth and population continue to increase. This study used Hoekman Index analysis to describe the level of openness of foreign retail services investment in ASEAN countries and SWOT analysis to find the strategies to utilize AFAS in order to increase Indonesia's overseas investment on retail industries in ASEAN markets. The results of the analysis concluded that the level of investment openness of ASEAN member countries for foreign retail services is relatively open; but, Indonesia is less open than other ASEAN countries. Furthermore, based on EFAS / IFAS Analysis, Indonesia's retail service sector has Opportunities and Strength as a way to develop its business in the ASEAN market with a strategy Progressive. As for other alternatives penetration strategies (entry mode) can be done, among others through full investment with foreign ownership of $100 \%$ to countries that have been fully open, joint venture, or through Indonesian retail franchise to ASEAN countries, which is the easiest and least risky way.
\end{abstract}

\section{Keywords-AFAS, SWOT, Hoekman Index}

\section{INTRODUCTION}

The service sector plays a very important role in the world economy and a country. Globally, in 2016 the service sector contributed $65 \%$ to world's GDP and absorbed a workforce of $50.7 \% .{ }^{1}$ World service exports are estimated at 5.4 trillion USD or $23 \%$ of total world's export ${ }^{2}$. The same is true in Indonesia. The contribution of the service sector in 2017 to Indonesia's GDP was $43.6 \%$, greater than the industrial sector by $39 \%$, and the agricultural sector by $13 \%$. In 2000-2017, the service sector grew an average of $7.1 \%$, higher than the industry sector $4.4 \%$ and agriculture sector $3.7 \%^{3}$. The service sector is also able to create jobs where in 2017 there were $47.6 \%$ of the population working in Indonesia working in the service sector ${ }^{4}$

In line with this, in the ASEAN region, the service sector also plays an important role in economic growth and creation of employment in ASEAN countries. In 2009 ASEAN total trade in services reached USD 343 billion or $5 \%$ of the share

${ }^{1}$ World Bank (WDI), 2019

${ }^{2}$ UNCTAD, 2019

${ }^{3}$ Statistics Indonesia, presented on $2^{\text {nd }}$ Focus Group Discussion in regard to Service Sector Development Planning at June 11, 2019

${ }^{4}$ Indonesian Labor Market Indicator: February 2017 of world services trade at that time. In 2015 the total ASEAN trade in services reached more than USD 610 billion, where the contribution of the service sector was estimated at $40 \%$ $70 \%$ of GDP for each ASEAN member country. With a total ASEAN population of more than 620 million people and a GDP value of USD 2.5 trillion, it can be an opportunity to expand the Indonesian service sector market to each ASEAN member country. ${ }^{5}$

As a concrete implementation of service trade liberalization in ASEAN, the ASEAN Framework Agreement on Services (AFAS) was established to provide market access and better investment opportunities for service business actors in ASEAN. The two main focuses of the liberalization agreement in AFAS are capital transfer flows (Mode 3) and movement of natural persons (Mode 4). This means that each member country provides more open market access for service business actors from other ASEAN countries to establish their business in fellow ASEAN partner countries. With AFAS, it is expected that the potential service business sectors can develop their business and become the main force in the framework of advancing the regional economy.

Although the service sector is important for its economy, Indonesia still relies on trade in goods compared to its services trade. Based on Indonesia's trade performance in 2016, the total value of trade in services amounted to USD 53.7 billion compared to the total trade value of goods which reached USD 273.4 billion. In the other words, the proportion of the value of services trade is only $16 \%$ of the total value of Indonesia's trade in 2016. In addition, Indonesia is also a net importer of services until today. From 2011 to 2016 Indonesia continues to experience a service balance deficit. The deficit of Indonesia's service balance is what later became one of the causes of Indonesia's current account continued to experience pressure from 2012 to 2015. Therefore, strategic steps are needed to be able to maximize all existing potential in order to secure Indonesia's trade balance, including utilizing the liberalization scheme in every cooperation agreement with trading partner countries to increase service exports.

In line with the utilization of service trade cooperation agreements that will be discussed in this paper, there are several previous studies that have discussed the utilization of cooperation agreements on trade in goods or services. Reference [1] shows the key factor for the success of retail

\footnotetext{
${ }^{5}$ ASEAN Services Integration Report 2015
} 
service exports in the case study is a local business partner who buys the master franchise. For this reason, the government can play a role in promotion and trade missions abroad to attract business partners. Moreover, regarding AFAS itself which has been running from 1995, refer to [2], as in [3], the request-and-offer approach adopted by ASEAN negotiators under the AFAS has been a rather time consuming and has had negligible impact on trade in services among the member countries. Therefore, according to [4], as in [3], they observed that AFAS would require a much greater political will by ASEAN, an increased sense of urgency and enhanced cooperation in ensuring better access data on services trade, increasing transparency with regards to laws and regulations, and a more target-oriented approach to liberalization of services by all ASEAN members.

Based on previous studies, this paper aims to look at openness level of foreign retail services investment in each ASEAN country and what is the strategy of using AFAS in order to increase Indonesia's retail services exports to the ASEAN market. This paper selects the retail service sector based on three main things. First, distribution services

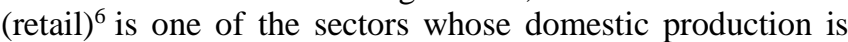
higher than the domestic demand (excess supply) so that the excess production can be a potential to be exported to markets in ASEAN. Second, the economy situation and population in ASEAN countries can become opportunities for business development and risk diversification of Indonesia's retail business. Third, the penetration of retail services from a country can be the initiation of greater entry of the country's manufactured goods to be exported.

The output of this study is expected to provide analytical results to utilize AFAS in Indonesian retail services and provide strategic recommendations in order to increase the export of Indonesian retail services to ASEAN.

\section{METHODOLOGY}

\section{A. Hoekman Index}

Referring to [5], as in [6], Hoekman Index (HI) is an indexation method proposed by Hoekman to measure the level of GATS-style commitment in the service sector [7]. HI values interpret the level of openness of a country compared to other countries in a framework of an agreement, or in other words how liberal a country is compared to others. The form of indexation in this method, if a country gives a commitment to the schedule of commitment in the form of none (full commitment) is given an index value of 1 . If opened with restrictions given an index value of 0.5 and if not committed (unbound) given an index value of 0 .

TABLE I. INDEXATION ON HOEKMAN INDEX

\begin{tabular}{|c|l|c|}
\hline No. & \multicolumn{1}{|c|}{ Commitment } & Hoekman Index \\
\hline 1 & None (full commitment) & 1 \\
\hline 2 & Limitation (open with certain restriction) & 0,5 \\
\hline 3 & Unbound (closed) & 0 \\
\hline
\end{tabular}

\section{B. Definition of SWOT Analysis, IFAS, and EFAS}

SWOT analysis is a tool used for strategic planning and strategic management in organizations. This can be used effectively to create organizational strategies, as in [8]. SWOT analysis is a simple but effective tool for measuring the resource capabilities of an organization and its weakness, market opportunities, and external threats in the future [9]. Data collection that will be analysed is generally done by distributing questionnaires to get the responses of selected respondents regarding the factors being studied, both external and internal factors. This study uses a purposive sample in the selection of respondents consisting of retail business owners, company managers, retail associations, and other decision makers in the retail business.

\section{EFAS/IFAS Analysis}

To facilitate the determination of the strategy for expansion of Indonesia's retail services sector into the ASEAN market with SWOT Analysis, a simple practice that can be used is to sort out external and opportunity factors with internal factors (strength and weakness) into a table. The instrument used to conduct environmental scanning is External Factor Analysis Summary (EFAS) and internal scanning is Internal Factor Analysis Summary (IFAS). EFAS is used to classify external factors (opportunities and threats) into a table based on generally accepted categories and analyse how well the respondent's assessment of these factors is in accordance with the conditions faced. Whereas, IFAS is used to classify internal factors (strengths and weaknesses) into a table based on generally accepted categories and analyze how well the respondent's assessment of these factors is in accordance with the conditions faced [10].

The following steps are carried out to produce an EFAS and IFAS table, namely:

1) Identify the factors that are opportunities and threats (EFAS) and strengths and weaknesses (IFAS);

2) Plotting the identified factors into an assessment table where the score of each factor is determined based on the weight and rating;

3) The weight is determined based on the ranking scale (ordinal). Respondents were asked to sort each variable from all identified variables. The amount of weight given to each factor shows how important these factors will support the success of an entity. If added together, the total weight of the overall factor is 1.0 ;

4) Next step, each factor is given a rating that shows the response to these factors. Ratings are determined based on a Likert scale (interval) where respondents are asked to rate one of the answers to 4 answer preferences. Each factor is then categorized into opportunities and threats based on the average rating of each factor;

5) The weight and rating are then multiplied to determine the weighted score for each factor.

6) The total difference in the average score for each opportunity and threat is used to see whether the opportunity is greater than the threat or vice versa. 
TABLE II. EFAS TABLE

\begin{tabular}{|c|c|l|l|l|}
\hline No. & OPPURTUNITY & WEIGHT & RATING & WEIGHTED SCORE \\
\hline 1 & & & & \\
\hline 2 & etc. & & & \\
\hline & Total of Oppurtunity & & & \\
\hline & & & & \\
\hline No. & THREAT & WEIGHT & RATING & WEIGHTED SCORE \\
\hline 1 & & & & \\
\hline 2 & etc. & & & \\
\hline & \multicolumn{5}{|c|}{ Total of Threat } & & & \\
\hline \multicolumn{5}{|c|}{ Total of Oppurtunity - Total of Threat = O - T =y } \\
\hline
\end{tabular}

TABLE III. IFAS TABLE

\begin{tabular}{|c|c|c|c|c|}
\hline No. & STRENGTH & WEIGHT & RATING & WEIGHTED SCORE \\
\hline \multicolumn{5}{|l|}{1} \\
\hline \multirow[t]{2}{*}{2} & etc. & & & \\
\hline & Total of Strenth & & & \\
\hline No. & WEAKNESS & WEIGHT & RATING & WEIGHTED SCORE \\
\hline \multicolumn{5}{|l|}{1} \\
\hline \multirow[t]{2}{*}{2} & etc. & & & \\
\hline & Total of Weakness & & & \\
\hline & tal of Strength - T & of We & kness $=\mathrm{S}$ & $5-W=x$ \\
\hline
\end{tabular}

Furthermore, the evaluation results table for each opportunity, threat, strength, and weakness indicator is then plotted into an EFAS / IFAS quadrant. There are 4 (four) strategy recommendations that can be produced in the EFAS / IFAS quadrant, namely Progressive, Diversification of Strategy, Change Strategy, and Survival Strategy. EFAS / IFAS quadrant as described in Figure 1.

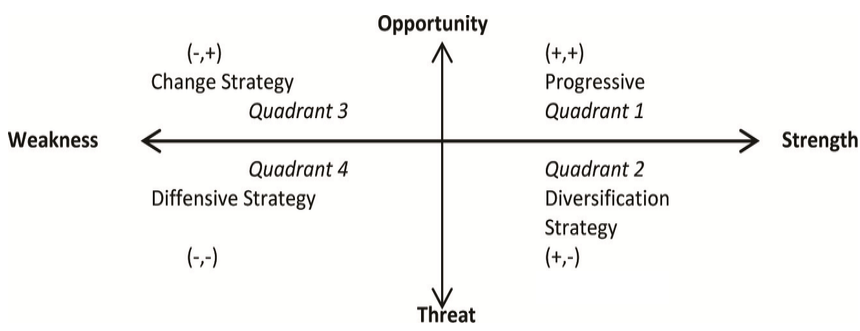

Fig. 1. EFAS/IFAS Quadrant

\section{RESULT AND DISCUSSION}

\section{A. Result of Hoekman Index Analysis}

Based on the calculation of the Hoekman Index (HI) in Mode 3 and Mode 4, the level of openness of retail services in each ASEAN country varies with the index value between 0.00 to 0.75 . Brunei Darussalam and the Philippines have an HI of 0 which indicates access to the retail services market in these countries is fully closed. Laos (HI: 0.13), Malaysia (HI: 0.25), and Thailand (HI: 0.38) indicate that market access is relatively closed. ASEAN countries that are considered open with restrictions are Indonesia (HI: 0.5), Singapore (HI: 0.5), Vietnam (HI: 0.5), and Myanmar (HI: $0.5)$. Meanwhile, Cambodia is an ASEAN country that is considered the most open market access with an HI value of
0.75. The complete HI calculation results are presented in Table 4.

TABLE IV. HOEKMAN INDEX ON RETAIL SERVICES IN ASEAN COUNTRIES

\begin{tabular}{|c|l|c|c|c|c|c|c|c|c|c|c|}
\hline \multirow{2}{*}{ NO. } & Retail Services Sector & \multicolumn{10}{|c|}{ Hoekman Index } \\
\hline & IND & SIN & MAL & THA & VIE & PHI & CAM & MYN & BRU & LAO \\
\hline 1 & $\begin{array}{l}\text { Openness on Foreign } \\
\text { Investment in Retail } \\
\text { Services Sector } \\
\text { (Mode 3 \& 4 }\end{array}$ & 0,5 & 0,5 & 0,25 & 0,38 & 0,50 & 0 & 0,75 & 0,50 & 0 & 0,13 \\
\hline 2 & Mode 3 & 0,5 & 1 & 0,25 & 0,75 & 1 & 0 & 1 & 1 & 0 & 0,25 \\
\hline & FEP (\%) & 51 & 100 & 51 & $49-70$ & 100 & 0 & 100 & 100 & 0 & 49 \\
\hline 3 & Mode 4 & 0,5 & 0 & 0,25 & 0 & 0 & 0 & 0,5 & 0 & 0 & 0 \\
\hline
\end{tabular}

Specifically, based on Table IV, it can be seen that Singapore, Vietnam, Cambodia, and Myanmar are countries that have opened Mode 3 (commercial presence) in full with HI by 1 . This openness is also indicated by the consistency of foreign equity participation (FEP) which is permitted at 100 percent in all four countries. Meanwhile, Thailand (HI: 0.75), Indonesia (HI: 0.5), Malaysia (HI: 0.25), and Laos (HI: 0.25$)$ open market access with restrictions where the amount of FEP varies between 49 percent up to 70 percent.

Furthermore, ASEAN countries tend to provide strict and closed restrictions on Mode 4 (movement of natural persons) which are indicated by index values varying between 0.00 to 0.50 . This means that ASEAN countries prioritize domestic workers rather than foreign workers. Although there is an AFAS roadmap available that encourages periodic liberalization in this Mode, each country tends to maintain a low commitment. Only Cambodia (HI: 0.5) and Indonesia (HI: 0.5 ) are relatively open in this Mode 4, while other countries are closed with an HI of 0.

Based on the analysis above, commitment in the AFAS Package 8 of ASEAN countries has not been fully open to the retail service sector. However, some countries can be said to be relatively open to foreign investment even though accompanied by restrictions including Cambodia, Singapore, Vietnam and Myanmar. The openness of market access is reflected in $\mathrm{HI}$ in Mode 3 by 1 and does not limit foreign ownership (FEP) to $100 \%$. However, each country is relatively closed to Mode 4, except Cambodia and Indonesia, in relation to regulating the flow of foreign workers.

\section{B. Result of SWOT Analysis}

\section{1) Result of External Factors Analysis Summary (EFAS)}

In Table V, there are 9 (nine) external factors assessed by respondents as Opportunities for the Indonesian retail service sector to expand their business in the ASEAN market. The Relatively Low Import Duty for Imported Goods between ASEAN Countries is rated highest by respondents with a rating of 3.00, followed by Consumption Behavior (2.92), Demography (2.80), Economic Conditions in Expansion Destination Countries (2.68), and so on. Otherwise, there are 4 (four) external factors assessed by respondents as Threats, namely Capital Return Rate (2.48), Conditions of Business Competition (2.48), Business Taxes for Foreign Retailers (2.48), and e-Commerce Development in the Expansion Destination (2.20). 
TABLE V. EFAS FROM QUESTIONER RESULT

\begin{tabular}{|c|c|c|c|c|}
\hline No. & Factor & Weight & Rating & Score \\
\hline \multicolumn{5}{|c|}{ Opprtunities } \\
\hline 1 & $\begin{array}{l}\text { Import Duty Tariff that is Relatively Lower than } \\
\text { ASEAN Countries }\end{array}$ & 0,06 & 3,00 & 0,17 \\
\hline 2 & $\begin{array}{l}\text { Consumption Behaviour in Expansion Destination } \\
\text { Countries (ASEAN) }\end{array}$ & 0,10 & 2,92 & 0,30 \\
\hline 3 & $\begin{array}{l}\text { Demography in Expansion Destination Countries } \\
\text { (ASEAN) }\end{array}$ & 0,06 & 2,80 & 0,17 \\
\hline 4 & $\begin{array}{l}\text { Economic Conditions in Expansion Destination } \\
\text { Countries (GDP, Inflation, Workforce) }\end{array}$ & 0,12 & 2,68 & 0,33 \\
\hline 5 & Workforce in Retail Services Sector & 0,06 & 2,68 & 0,16 \\
\hline 6 & $\begin{array}{l}\text { Domestic Regulation in Expansion Destination } \\
\text { Countries (ASEAN) }\end{array}$ & 0,11 & 2,64 & 0,29 \\
\hline 7 & $\begin{array}{l}\text { Distribution Channels and Logistic in Expansion } \\
\text { Destination Countries (ASEAN) }\end{array}$ & 0,08 & 2,64 & 0,20 \\
\hline 8 & $\begin{array}{l}\text { Entry Mode Option in Expansion Destination } \\
\text { Countries (ASEAN) }\end{array}$ & 0,04 & 2,56 & 0,10 \\
\hline 9 & $\begin{array}{l}\text { Acceptance of Indonesian Product on Global } \\
\text { Value Chain }\end{array}$ & 0,04 & 2,56 & 0,10 \\
\hline & \multicolumn{3}{|l|}{ Total } & 1,81 \\
\hline \multicolumn{5}{|c|}{ Threats } \\
\hline 10 & $\begin{array}{l}\text { Capital Return Rate in Expansion Destination } \\
\text { Countries (ASEAN) }\end{array}$ & 0,10 & 2,48 & 0,25 \\
\hline 11 & $\begin{array}{l}\text { Retail Business Competitive Conditions in } \\
\text { Expansion Destination Countries (ASEAN) }\end{array}$ & 0,10 & 2,48 & 0,25 \\
\hline 12 & $\begin{array}{l}\text { Business Taxes on Foreign Retail Services } \\
\text { Company in ASEAN Countries }\end{array}$ & 0,07 & 2,48 & 0,16 \\
\hline 13 & $\begin{array}{l}\text { E-commerce Development in Expansion } \\
\text { Destination Countries (ASEAN) }\end{array}$ & 0,07 & 2,20 & 0,15 \\
\hline & \multicolumn{3}{|l|}{ Total } & 0,82 \\
\hline & \multicolumn{3}{|l|}{ "Opprtunities - Threats } & 1,00 \\
\hline
\end{tabular}

Overall, the opportunity (total score of 1.81) is greater than the threat (total score of 0.82). This means that the Indonesian retail service sector can consider developing its business in the ASEAN market because the opportunity is greater than the threat that must be faced with a value difference of 1.00 .

\section{2) Result of External Factors Analysis Summary (EFAS)}

In Table VI, there are 9 (nine) internal factors assessed by respondents as Strengths that can be the capital of Indonesian retailers to develop their business in ASEAN markets. The condition of the Indonesian economy is rated highest by respondents with a rating of 3.20 , followed by Labor in the Retail Services Sector (3.16), Indonesian Retailer Governance/Management (2.96), and so on. On the contrary, there are 4 (four) internal factors that respondents consider as Weaknesses, namely the Indonesian Distribution and Logistic Network to ASEAN Countries (2.44), Business Taxes for Retailers Doing Expansion (2.20), Affiliation with Overseas Partners (2.12), and Experience of Foreign Expansion by Indonesian Retailers (2.00).

Overall, Strength (total score of 2.11) is greater than Weakness (total score of 0.59). This means, the Indonesian retail service sector is able to capture opportunities in the ASEAN market because its strength is greater than its weakness with a value difference of 1.53.
TABLE VI. IFAS FROM QUESTIONER RESULT

\begin{tabular}{|c|c|c|c|c|}
\hline \multirow{2}{*}{\multicolumn{5}{|c|}{\begin{tabular}{|l|} 
No. \\
Strengths \\
\end{tabular}}} \\
\hline & & & & \\
\hline & $\begin{array}{l}\text { Indonesia Economic Condition (GDP, Inflation, } \\
\text { Workforce) }\end{array}$ & 0.12 & 3.20 & 0.40 \\
\hline 2 & Workforce on Retail Services Sector (Expenses, Skill) & 0.07 & 3.16 & 0.23 \\
\hline 3 & Management of Indonesia Retail Services Company & 0.09 & 2.96 & 0.26 \\
\hline 4 & Indonesia Retail Services Scale of Business & 0.07 & 2.92 & 0.22 \\
\hline 5 & $\begin{array}{l}\text { The Capability to Applicate Technology by the } \\
\text { Indonesian Retail Services Company }\end{array}$ & 0.08 & 2.84 & 0.22 \\
\hline 6 & $\begin{array}{l}\text { The Capability of Indonesian Product to Enter Global } \\
\text { Value Chain }\end{array}$ & 0.06 & 2.80 & 0.17 \\
\hline 7 & Policy on Retail Businesses in Indonesia & 0.09 & 2.76 & 0.24 \\
\hline 8 & Brand of Indonesian Retail Services Company & 0.08 & 2.56 & 0.21 \\
\hline \multirow[t]{2}{*}{9} & The Income of Indonesian Retail Services Business & 0.07 & 2.56 & 0.18 \\
\hline & \multicolumn{3}{|l|}{ Total } & 2.11 \\
\hline \multicolumn{5}{|c|}{ Weaknesses } \\
\hline 10 & $\begin{array}{l}\text { Distribution Channels and Logistic to ASEAN } \\
\text { Countries }\end{array}$ & 0.07 & 2.44 & 0.17 \\
\hline 11 & $\begin{array}{l}\text { Business Taxes for Abroad Expanding Retail Services } \\
\text { Company }\end{array}$ & 0.05 & 2.20 & 0.12 \\
\hline \multirow{4}{*}{$\begin{array}{l}12 \\
13 \\
\end{array}$} & Affiliation with Abroad Partner & 0.06 & 2.12 & 0.14 \\
\hline & Overseas Expansion Experience & 0.08 & 2.00 & 0.16 \\
\hline & Total & & & 0.59 \\
\hline & Strengths - Weaknesses & & & 1.53 \\
\hline
\end{tabular}

In Figure 2, a greater chance of a threat of 1.00 and a strength greater than weakness of 1.53 are in quadrant I $(\mathrm{O}$ : positive, S: positive). This means that Indonesia's retail services sector has the opportunity and strength as capital to develop its business in the ASEAN market with a Progressive strategy. The alternative mode of entry that can be done, among others, through direct investment with foreign ownership of $100 \%$ to countries that have been fully open. Meanwhile, for countries that still apply restrictions on foreign retail ownership in their countries, Indonesian retailers can consider the entry of joint venture modes with strategic partners in the country. Joint ventures can also be considered by Indonesian retailers to reduce business risks that may exist in each country. In addition, Indonesian retailers can also sell their master franchise business to retail businesses in ASEAN countries, which is the easiest and least risky way.

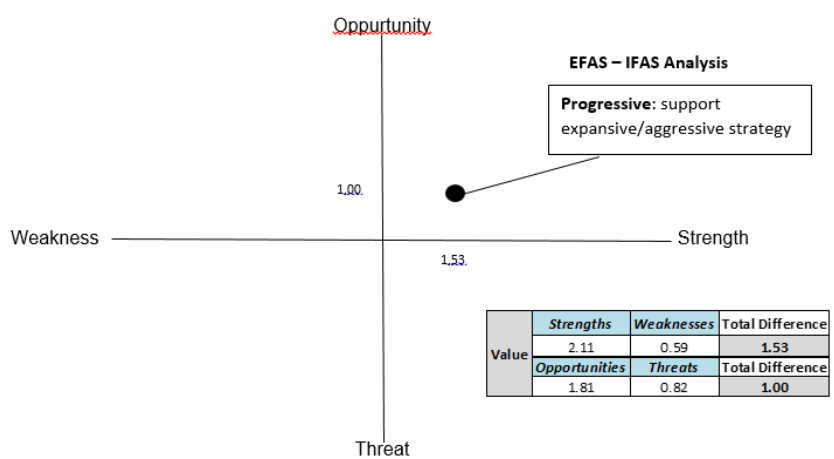

Fig. 2. Strategy to Enhance Indonesia's Retail Services Export to ASEAN Market 


\section{CONCLUSION AND POLICY RECOMMENDATION}

\section{A. Conclusions}

Based on the results of the analysis using the Hoekman Index method, and EFAS / IFAS Analysis can be concluded in two. First, the level of openness for investment of retail services in ASEAN countries in like Cambodia, Singapore, Vietnam, Myanmar and Thailand is relatively more open than other ASEAN countries, both in their commitment in AFAS and in their domestic regulations. Furthermore, the Philippines, Malaysia and Laos are relatively closed countries in AFAS, but actually are more open to their domestic regulations. Meanwhile, Brunei Darussalam and Indonesia are considered closed both in their commitment to AFAS and domestic regulations.

Second, Indonesia's retail service sector, from SWOT analysis, has Opportunities and Strength as a way to expand its retail business to ASEAN market with a Progressive strategy. As for alternative entry mode that can be done, among others, through direct investment to get $100 \%$ foreign ownership to countries that are fully open in its retail service sector access, full joint venture, or through Indonesia's retail franchise to businessmen in ASEAN countries, as an easier and relatively less risky way.

\section{B. Policy Recommendations}

Indonesian retailers can consider Cambodia, Singapore, Vietnam, Myanmar and Thailand as the main destination countries for retail business expansion because their level of openness is relatively open than other ASEAN countries. The government, through the Ministry of Trade and representatives of the Republic of Indonesia in ASEAN countries, needs to actively provide education, support, and encouragement including assistance, especially at the G-to-G and / or G-to-B levels to bridge and facilitate business cooperation in the target countries for expansion, for example by disseminating information about ASEAN market investment openness, retail business opportunities in ASEAN markets, and retail rules / policy information in destination countries.

The government and stakeholders need to improve some of the weaknesses of the Indonesian retail services and products sector in the ASEAN market, such as strengthening distribution and logistics channels from Indonesia to ASEAN countries and providing fiscal and non-fiscal incentives for retail service businesses that expand abroad. Furthermore, to improve weaknesses in terms of "affiliation with foreign partners" and "experience of overseas expansion", the Ministry of Trade can provide facilitation / assistance, such as business matching and business advocacy, so that Indonesian retailers can find strategic partners in target countries purpose of expansion.

\section{ACKNOWLEDGMENT}

This paper is made based on research conducted by Center of International Trade Research of International Trade Coorperation in 2018 budget year. The authors would like to thank to all fellows involved especially Leo Mualdy Christoffel, Endah Ayu Ningsih, Muhammad Fawaiq, and Steven Raja Ingot for giving their best contribution in this research.

\section{REFERENCES}

[1] Fawaiq, M., "Analysis on Indonesian Retail Services Entry Mode into ASEAN: A Case Study on Alfamart",The Agency of Trade Research and Development, Ministry of Trade, 2015.

[2] Austria, M. \& Avila, J., "Looking beyond AFTA: prospects and challenges for inter-regional trade", PIDS Discussion Paper Series No.2001-10, Makati City: the Philippine Institute for Development Studies, 2002

[3] Rajan, R. and R. Sen, "Liberalization of Financial Services in Southeast Asia under the ASEAN Framework Agreement on Service (AFAS)", October 2002

[4] Nikomborirak, D., \& Stephenson, S., "Liberalization of Trade in Services: East Asia and the Western Hemisphere", Paper prepared for the Pacific Economic Cooperation Council (PECC), Trade Policy Forum on Regional Trading Arrangements, Bangkok, Thailand (12-13 June), 2001.

[5] Ishido, H., "Liberalization of Trade in Services under ASEAN+n FTA: A Mapping Exercise", Journal of East Economic Integration, Vol. 16, (2), 155-204, 2012

[6] Mardiansyah, A., "Investment policy reforms to improve the efficiency of Indonesia's trade logistics cost to ASEAN region", The $1^{\text {st }}$ International Conference and Call for Paper on Trade, Indonesia: the Ministry of Trade, Vol. 1, pp. 1-18, 2017.

[7] Hoekman, B., "Assessing the General Agreement on Trade in Services", in Will Martin and L. Alan Winters (eds.), The Uruguay Round and the Developing Countries, World Bank Discussion Paper No. 307, Washington, D.C.: The World Bank, 1995.

[8] Gurel, E. \& Tat, M., "SWOT Analysis: A Theoretical Review", The Journal of International Social Research, Vol. 10, Issue 51, 2017.

[9] Thompson, A.A., Strickland A.J., \& Gamble, J.E., "Crafting and Executing Strategy-Concepts and Cases", McGraw-Hill, 2007.

[10] Wheelen, T.L. \& Hunger, J.D., "Strategic Management and Business Policy", New Jersey: Pearson Education, 2002. 